\title{
Physico-chemical and sensory properties of strawberries (Fragaria x ananassa) grown in conventional and hydroponic systems
}

\author{
Maria Lucilania Bezerra Almeida ${ }^{1 *}$, Carlos Farley Herbster Moura ${ }^{2}$, Renato Innecco ${ }^{1}$, Deborah dos Santos \\ Garruti $^{2}$, Fábio Rodrigues de Miranda², Márcia Régia Souza da Silveira ${ }^{2}$ \\ ${ }^{1}$ Federal University of Ceará, Department of Plant Science, Av. Mister Hull, bloco 805, 60.356-000, Fortaleza-CE, \\ Brazil \\ ${ }^{2}$ Embrapa Tropical Agroindustry, Rua Dra. Sara Mesquita, 2270, 60511-110, Fortaleza-CE, Brazil
}

\section{*Corresponding author: lucilanialmeida@hotmail.com}

\begin{abstract}
Strawberry is considered a fruit of great commercial interest in many countries due to its color, aroma, flavor, and nutritional properties. However, it is possible that the differences among the cultivation systems could affect the production of photoassimilates in the plant and, consequently, their partitioning into the fruits composition, influencing its quality. Therefore, the aim of this work was to evaluate the influence of the cultivation systems (hydroponics in gutters and slabs, and conventional) and genotype on the physicochemical properties, antioxidant and sensory activity in strawberry fruits. The experiment was carried out using a completely randomized design in a factorial $4 \times 3$ scheme with four replications, represented by trays of a pproximately 200 $\mathrm{g}$ of fruit. In the Laboratory, the strawberries (cv. Oso Grande, Festival, Camarosa, and Albion) were analyzed for their physicochemical properties and sensory variables: titratable acidity (TA), soluble solids (SS), SS/TA ratio, soluble sugars, vitamin C, polyphenol, and antioxidant activity. It was observed that cultivation systems and genotype studied influence the antioxidant activity, physicochemical and sensory properties of strawberries. The conventional system shows higher values for physicochemical variables and antioxidant activity, with cultivar variation within each system. The antioxidant activity attributed to strawberry is strongly related to the content of extractable polyphenols and vitamin C. Regarding the sensory properties, cultivars show good overall acceptability in all production systems studied, no presenting difference among systems.
\end{abstract}

Keywords: antioxidant activity, cultivars, fruit quality, sensory analysis.

\section{Introduction}

Strawberry is considered a fruit of great commercial interest in many countries due to its color, aroma, flavor and nutritional properties, which make the fruit a product of high commercial value and much appreciated by consumers (Costa et al., 2011; Giménez et al., 2008).

Fruits nutritional composition make them a food of great interest and important for the human diet. It is genetically established, thus, without human intervention, since the quality does not go beyond what determines the capacity of the genes. However, the plants must be subject to several factors, such as nutritional requirements (Aular and Natale, 2013) and appropriate soil and climatic conditions, to occur the expression of all their genetic potential.

The strawberry has excellent sensory characteristics, but it is highly perishable, with limited postharvest life due to high moisture content, sugars and acids, therefore making it an ideal substrate for proliferation of pathogenic organisms that cause considerable postharvest damage (Siqueira et al., 2009). One of its main physiological characteristics is the fact that it is a non-climacteric fruit (Pineli et al., 2011), and after harvesting, ripening or improvement in sensory characteristics does not occur (Chitarra and Chitarra, 2005). The strawberry crop has good potential to expand to the mild climate regions in the state of Ceará, Brazil, especially in the mountainous region. The first crops in this region were planted in 2009 by growers who came from traditional strawberry crop regions. These growers proved that the crop is well suited for the region's climate, with respect to precocity and low incidence of pests and diseases. Therefore, there is a reduction in production costs compared to strawberry traditional growing areas.

In this scenario, the incorporation of new technologies for increasing yield and strawberry quality, are being researched, such as the type of cropping system. The conventional system is characterized by high use of defensive chemicals that promote a substantial reduction in fruit quality in function of agrochemical residue; however, other systems have been tested, such as the hydroponic system. On the system, the plants are grown on a substrate and fertigated with a nutrient solution and may be an alternative to provide balanced nutrition to the plant, with 
high productivity and better quality fruit. The proposed system is implemented under protected cultivation, which features plants with lower incidence of pests and diseases, reducing the use of chemicals; it improves the acceptance and safety of the product for the consumer.

The cultivation in a protected environment facilitates the growth and development of the plants in times of the region when the climatic conditions are limiting (Heldwein et al., 2010). In recent years, it has expanded as a means of protecting seasonality in the supply of products throughout the year. This becomes a possible practice because this type of environment causes significant changes in temperature, relative humidity, luminosity, wind speed, among others.

Therefore, the aim of this work was to evaluate the influence of the cultivation systems (hydroponics in gutters and slabs, and conventional) and genotype on the physicochemical properties, antioxidant and sensory activity in strawberry fruits.

\section{Results and discussion}

\section{Quantification of physicochemical variables}

Plants in the hydroponic systems looked healthier and vigorous, probably due to the fact that nutritional and climatic conditions provided by this environment allowed greater expression of the physiological activities, and therefore, higher accumulation of carbohydrates which result in the increase of biomass (Taiz et al., 2017), resulting in larger strawberries. Plants in the conventional production system were less vigorous, probably due to stress conditions, which resulted in smaller berries and a higher content of defense compounds.

Soluble sugar and total extractable polyphenol variables showed differences for systems and cultivars (Table 1). The soluble sugars of strawberries grown in gutters and conventional systems showed the highest mean values, differing from the slab system. The cv. Albion showed higher sugar content, which differed only in the cv. Oso Grande, which in turn did not differ from the others. Similar results relative to the cultivars of this work were obtained by Figueiredo et al. (2010).

The soluble sugar content in strawberries of the conventional production system can be explained by the fact that the crop was grown in full sunlight, therefore resulting in the increased production of photosynthates, and partition of the same for the composition of the fruit. In turn, the content observed in the gutter system, may be due to the use of fertigation, not used in the conventional system, and less competition between plants, when compared with the slab system. The slab system had higher plant density (13.3 plants per $\mathrm{m}^{-2}$ compared to 10.0 plants $\mathrm{m}^{-2}$ in the gutter system) which may have leads to shading resulting in competition for light, nutrients, and water.

For content of total extractable polyphenols (TEP), strawberries of the conventional system presented the highest means. Comparing cultivars, cv. Festival (120.45 mg $100 \mathrm{~g}^{-1}$ ) stood out with highest polyphenol content (Table 1). Greater values of TEP in the conventional system was probably due to the plants growing in full sunlight, environment more vulnerable to certain conditions of stress, leading them to produce substances known as secondary metabolites to be used as a defense against pathogens, herbivores and radiation. This is corroborated by Melo et al. (2008), by stating that the production of polyphenols depends on the intrinsic (cultivar, variety and maturity stage) and extrinsic (climate and soil conditions) factors and the methods of plant protection. Values of the polyphenols higher than those of the present study were observed by Kuskoski et al. (2006) in frozen solid strawberry pulp (mean

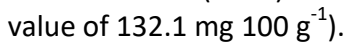

In respect to soluble solids (SS), titratable acidity (TA) and SS/TA ratio, there was an interaction between production systems and cultivars (Table 2). The Oso Grande and Albion cultivars stood out with the highest mean values of soluble solids in the conventional system. In the hydroponic gutter system, the best performance was observed in the cv. Camarosa. In the slab system, all the cultivars had a good performance, with the exception of the cv. Festival.

This higher values of SS in the conventional system is directly related to the higher amount of sugars, polyphenols, and vitamin $C$, among other compounds. This result can be explained by the probable stress caused by the climatic conditions, leading to higher plant conversion of carbohydrates into soluble sugar, which represent about 65$85 \%$ of SS (Chitarra and Chitarra, 2005; Lado et al., 2014), and other compounds such as organic acids and nitrogenous compounds, instead of being used to increase the size of strawberries. Therefore, one can see that the soluble solids vary among cultivars, production systems and environmental conditions.

Lower SS level results than those found in the present study were observed in the Camarosa and Oso Grande cultivars in studies in Paraná (Resende et al., 2010), and higher SS levels in the cv. Oso Grande were found by Camargo et al. (2011). For cv. Festival, Atress et al. (2010) found higher SS values in studies performed in Egypt.

In relation to titratable acidity, strawberries of the conventional and the hydroponic slab systems presented the lowest and highest averages, respectively (Table 2). Comparing different cultivars in each production system, we observed that in the hydroponic gutter system, the largest value of TA was in the cv. Camarosa, not differing from the Festival and Albion cultivars. In the hydroponic slab system, the highest values were found in Festival and Camarosa cultivars. In the conventional system, the cv. Oso Grande is best for producing strawberries with lower acidity.

The TA values were high when compared to those found for strawberries produced in other regions, which can be explained by climatic conditions such as higher temperatures, observed in the Ibiapaba region, compared to traditional growing regions, resulting in a more acidic strawberry. When high daytime and/or nighttime temperature occurs, the strawberry can become overly acidic, often poor in taste and aroma and with less consistency, which was not observed in the present study.

Considering the SS/TA ratio, which is a key variable of the commercial fruit quality, the highest average was found in strawberries of the conventional system, especially cv. Oso Grande (Table 2). In the gutter system, all cultivars showed the same behavior, represented by the highest averages, with the exception of the cv. Albion. In the slab system, the highest means were observed in Albion and Oso Grande cultivars. Superior results of SS/TA were obtained in studies 
Table 1. Mean values of soluble sugars (SA) and total extractable polyphenols (TEP) of the fruit of four strawberry cultivars grown in three different production systems.

\begin{tabular}{lll}
\hline Systems & SA (\%) & TEP $\left({\left.\mathrm{mg} 100 \mathrm{~g}^{-1}\right)}^{-1}\right.$ \\
\hline Gutters & $5.00 \mathrm{a}$ & $99.75 \mathrm{~b}$ \\
Slabs & $4.21 \mathrm{~b}$ & $94.00 \mathrm{~b}$ \\
Conventional & $5.18 \mathrm{a}$ & $116.83 \mathrm{a}$ \\
\hline Cultivars & & \\
\hline Oso grande & $4.55 \mathrm{~b}$ & $104.78 \mathrm{~b}$ \\
Festival & $4.78 \mathrm{ab}$ & $120.45 \mathrm{a}$ \\
Camarosa & $4.79 \mathrm{ab}$ & $95.55 \mathrm{c}$ \\
Albion & $5.07 \mathrm{a}$ & $93.33 \mathrm{c}$ \\
\hline Mean value & 4.8 & 103.53 \\
CV (\%) & 6.54 & 6.58 \\
\hline
\end{tabular}

Means followed by the same letter in columns do not differ by the Tukey test at 0.05 significance.

Table 2. Soluble solids (SS), titratable acidity (TA) and SS/TA of the fruit of four strawberry cultivars grown in three different production systems.

\begin{tabular}{|c|c|c|c|c|c|c|c|c|c|}
\hline \multirow[b]{2}{*}{ Cultivars } & \multicolumn{3}{|l|}{ SS (ㅇ Brix) } & \multicolumn{4}{|c|}{ TA (\% citric acid) } & \multicolumn{2}{|l|}{ SS/TA } \\
\hline & Gutters & Slabs & Conventional & Gutters & Slabs & Conventional & Gutters & Slabs & Conventional \\
\hline Oso grande & $7.20 \mathrm{bBC}$ & $6.73 \mathrm{cAB}$ & 8.13 aAB & $1.28 \mathrm{aB}$ & $1.41 \mathrm{aBC}$ & $1.10 \mathrm{bB}$ & $5.61 \mathrm{bA}$ & $4.78 \mathrm{cAB}$ & $7.43 \mathrm{aA}$ \\
\hline Festival & $7.43 \mathrm{aB}$ & $6.63 \mathrm{bB}$ & $7.70 \mathrm{aBC}$ & $1.37 \mathrm{bAB}$ & $1.54 \mathrm{aAB}$ & $1.39 \mathrm{bA}$ & $5.41 \mathrm{aAB}$ & $4.52 \mathrm{bB}$ & $5.55 \mathrm{aC}$ \\
\hline Camarosa & $8.20 \mathrm{aA}$ & $6.93 \mathrm{cAB}$ & $7.43 \mathrm{bc}$ & $1.52 \mathrm{aA}$ & $1.61 \mathrm{aA}$ & $1.26 \mathrm{bA}$ & $5.38 \mathrm{bAB}$ & $4.33 \mathrm{cB}$ & $5.95 \mathrm{aBC}$ \\
\hline Albion & $6.93 \mathrm{bc}$ & $7.13 \mathrm{bA}$ & $8.55 \mathrm{aA}$ & $1.39 \mathrm{aAB}$ & $1.36 \mathrm{aC}$ & $1.32 \mathrm{aA}$ & $4.99 \mathrm{bB}$ & $5.23 \mathrm{bA}$ & $6.50 \mathrm{aB}$ \\
\hline Mean value & & 7.41 & & & 1.38 & & & 5.47 & \\
\hline CV (\%) & & 2.95 & & & 4.78 & & & 4.90 & \\
\hline
\end{tabular}

Means followed by the same lowercase letters in rows and uppercase letters in columns do not differ by the Tukey test at 0.05 significance.

Table 3. Vitamin $\mathrm{C}$ and total antioxidant activity (TAA) in the fruit of four strawberry cultivars grown in three different production systems.

\begin{tabular}{|c|c|c|c|c|c|c|}
\hline \multirow{2}{*}{ Cultivars } & \multicolumn{3}{|c|}{ Vitamin C (mg $\left.100 \mathrm{~g}^{-1}\right)$} & \multicolumn{3}{|c|}{ TAA $\left(\mu \mathrm{M}\right.$ Trolox $\left.\mathrm{g}^{-1}\right)$} \\
\hline & Gutters & Slabs & Conventional & Gutters & Slabs & Conventional \\
\hline Oso grande & $57.67 \mathrm{bA}$ & $59.99 \mathrm{bA}$ & $74.03 \mathrm{aA}$ & $9.76 \mathrm{aA}$ & $8.69 \mathrm{aAB}$ & $9.49 \mathrm{aB}$ \\
\hline Festival & $54.33 \mathrm{bA}$ & $56.60 \mathrm{bA}$ & $66.73 \mathrm{aB}$ & $6.64 \mathrm{cB}$ & 9.42 bA & $11.94 \mathrm{aA}$ \\
\hline Camarosa & $54.15 \mathrm{aA}$ & $48.13 \mathrm{aB}$ & $49.30 \mathrm{aC}$ & $8.90 \mathrm{aAB}$ & $6.61 \mathrm{bB}$ & $10.11 \mathrm{aAB}$ \\
\hline Albion & $59.38 \mathrm{bA}$ & $56.36 \mathrm{bA}$ & $76.73 \mathrm{aA}$ & $6.79 \mathrm{bB}$ & $6.60 \mathrm{bB}$ & $10.95 \mathrm{aAB}$ \\
\hline Mean value & & 59.45 & & & 8.83 & \\
\hline CV (\%) & & 5.07 & & & 12.30 & \\
\hline
\end{tabular}

Means followed by the same lowercase letters in rows and uppercase letters in columns do not differ by the Tukey test at 0.05 significance. 
Table 4. The Pearson correlation coefficients between bioactive compounds and total antioxidant activity of the fruit of four strawberry cultivars grown in three different production systems.

\begin{tabular}{|c|c|c|c|c|}
\hline \multirow{2}{*}{ Variables } & \multicolumn{4}{|c|}{ Total antioxidant activity } \\
\hline & Oso Grande & Festival & Camarosa & Albion \\
\hline Vitamin C & $-0.0467^{\text {ns }}$ & $0.8079 *$ & $0.4005^{\text {ns }}$ & $0.8579 *$ \\
\hline Total extractable polyphenols & $0.0658^{\mathrm{ns}}$ & $0.7743 *$ & $0.7338^{*}$ & $0.8803 *$ \\
\hline
\end{tabular}

Table 5. Average hedonic values of acceptance of strawberry samples grown in hydroponic and conventional system. Hydroponic system

\begin{tabular}{lcc}
\hline Cultivars & Overall Acceptance & Acceptance of Appearance \\
\hline Oso Grande & $7.29 \mathrm{a}$ & $7.35 \mathrm{a}$ \\
Camarosa & $6.69 \mathrm{ab}$ & $5.85 \mathrm{~b}$ \\
Festival & $7.35 \mathrm{a}$ & $7.35 \mathrm{a}$ \\
Albion & $6.64 \mathrm{~b}$ & $7.58 \mathrm{a}$ \\
\hline Conventional system & & \\
\hline Cultivars & Overall Acceptance & Acceptance of Appearance \\
\hline Oso Grande & $6.94 \mathrm{a}$ & $6.08 \mathrm{~b}$ \\
Festival & $7.21 \mathrm{a}$ & $7.06 \mathrm{a}$ \\
\hline Means followed by the same letter in columns do not differ by the Tukey test at 0.05 significance.
\end{tabular}

Table 6. Mean intensity of sensory attributes (Diagnostic of Attributes test) of strawberry samples grown in hydroponic and conventional system.

\begin{tabular}{lcccc}
\hline Hydroponic system & \multicolumn{5}{l}{} \\
\hline Cultivars & Red coloring & Strawberry's flavor & Acid taste & Juiciness \\
\hline Oso Grande & $5.04 \mathrm{c}$ & $5.27 \mathrm{a}$ & $3.32 \mathrm{c}$ & $5.64 \mathrm{ab}$ \\
Camarosa & $4.22 \mathrm{~d}$ & $4.90 \mathrm{a}$ & $5.84 \mathrm{a}$ & $4.72 \mathrm{~b}$ \\
Festival & $7.75 \mathrm{a}$ & $5.60 \mathrm{a}$ & $4.88 \mathrm{~b}$ & $5.77 \mathrm{a}$ \\
Albion & $6.40 \mathrm{~b}$ & $5.34 \mathrm{a}$ & $6.01 \mathrm{a}$ & $5.03 \mathrm{ab}$ \\
\hline Conventional system & & & \\
\hline Cultivars & Red coloring & Strawberry's flavor & Acid taste & Juiciness \\
Oso Grande & $6.15 \mathrm{~b}$ & $5.25 \mathrm{a}$ & $3.47 \mathrm{~b}$ & $6.21 \mathrm{a}$ \\
Festival & $7.29 \mathrm{a}$ & $5.69 \mathrm{a}$ & $5.00 \mathrm{a}$ & $5.31 \mathrm{~b}$ \\
\hline
\end{tabular}

Means with same letter in the same column do not differ significantly by the $F$ test at 0.05 .

by Borsatti et al. (2009) in ten strawberry cultivars grown under organic system for Oso Grande, Festival and Camarosa cultivars $(6.29,7.27$, and 6.86, respectively).

For vitamin $\mathrm{C}$ and total antioxidant activity, difference for the interaction between the factors studied (Table 3 ) was observed. In relation to vitamin C, the highest content was observed in the conventional system, especially the Oso Grande and Albion cultivars with superior results compared to other cultivars. As for the gutter and slab systems, the cultivars showed the same behavior, with the exception of the cv. Camarosa in the slab system, which presented the lower values. From the results obtained in this study, one can see that the strawberry has a reasonable amount of vitamin $\mathrm{C}$, which varies between varieties and production systems.

The difference in vitamin $\mathrm{C}$ content among production systems might be associated with the influence of cropping and climatic conditions. In the hydroponic system, the plants showed more vigorous and hardwood than the conventional one, causing a greater proximity among them, making it difficult the penetration of light. Thus, plants subjected to a longer period with less light may have led to a reduction in the synthesis of ascorbic acid. Therefore, luminosity is required in the biosynthesis of ascorbic acid, which is synthesized from the sugars produced in photosynthesis (Chitarra and Chitarra, 2005). Thus, the lower ascorbic acid content of fruits produced in the hydroponic system is probably a consequence of the lower luminosity in this environment, due to being installed in a protected environment.

In addition, ascorbic acid in its pure form, it is quite unstable, easily destroyed by oxidation, particularly high temperature, light, moisture, alkalinity, metal catalysts and physical damages (Beltrán-Orozco et al., 2009). Based on this, it is probable that one or more of these factors induced the oxidation of same in the hydroponic systems. This could also be a result of the fact that ascorbic acid is a primary plant metabolite and acts as an antioxidant that may have led the strawberries of the conventional system to produce a greater amount of vitamin C, aiming at the plant's defense system.

\section{Total antioxidant activity}

The total antioxidant activity (Table 3 ) showed the best results in the conventional system, for which the cultivars showed similar behavior, with the exception of the cv. Oso Grande, which had the lowest value. In the gutter system, the Oso Grande and Camarosa cultivars showed higher values. In the slab system the greatest amounts of TAA were observed in the Oso Grande and Festival cultivars. The increase in TAA occurs most often in stressful situations, 
such as in the conventional system without the protected environment. In this case, probable stress conditions were above the tunnel, which led the plants to produce more compounds to be used as a defense, if necessary. This may have been an indication of why many of the characteristics evaluated were higher in the strawberries produced in the conventional system.

In studies with strawberries, Pineli et al. (2011) using the FRAP and DPPH method, obtained $12.83 \mu \mathrm{mol} \mathrm{g}^{-1}$ and 27.37 $\mu \mathrm{mol} \mathrm{g}{ }^{-1}$, respectively in the $\mathrm{cv}$. Oso Grande at ripe stage.

\section{Pearson's correlation coefficients}

In the Pearson's correlation analysis, there was a significant positive correlation for vitamin $\mathrm{C}$ and total extractable polyphenols $(p<0.05)$ (Table 4$)$. For vitamin C, a significant correlation for the Festival and Albion cultivars was observed. For the TEP variable, only the cr. Oso Grande showed no significant correlation. This shows that these variables are some of the TAA contributors, and the higher content of vitamin C and TEP, the greater the TAA, in some of these cultivars.

\section{Sensory analysis}

Table 5 shows the mean acceptance of cultivars in hydroponic systems. In Figures $1 \mathrm{~A}$ and $1 \mathrm{~B}$ one can see the distribution of the hedonic value frequencies for each sample compared to the overall acceptance and acceptance of appearance, respectively, for hydroponic systems. All samples showed good overall acceptability, with averages around 7, corresponding to the "like" on the hedonic scale. Oso Grande and Festival cultivars differed from the Albion cultivar, which received a lower overall acceptance. However, by analyzing the histograms (Figure 1A), some differences in the distribution of the frequencies of hedonic values were observed.

Oso Grande and Festival cultivars scored in category 8 (like very much), but the $\mathrm{cv}$. Festival received a greater frequency of responses in the highest category of the scale (like extremely), indicating that this cultivar was more accepted. The Camarosa and Albion cultivars, despite having very similar averages, show distinct distribution frequencies, and the cv. Albion scored $33 \%$ of the responses in category 7 (liked), compared to $29 \%$ of the responses in category 6 (like slightly) for the cv. Camarosa, indicating that the latter was a less accepted cultivar.

For the acceptance of appearance, the cv. Camarosa was less accepted, which may have influenced the overall acceptance (Table 5). For the other cultivars, although no difference among the means was detected, it was observed by means of the histograms in Figure $1 \mathrm{~B}$, that the $\mathrm{cv}$. Albion showed higher acceptability than the others, with $73 \%$ of the responses in the maximum categories of the hedonic scale ( 8 and 9). The cv. Festival presented $60 \%$ of the responses in categories 8 and 9, while the answers to the cv. Oso Grande were well distributed around the 7 (liked).

In the analysis of the acceptance of strawberries of the conventional system (Table 5), both evaluated cultivars showed good overall acceptability, with averages around 7, corresponding to the "like" on the hedonic scale, not differing. However, through the means of histograms of
Figure 1C, a slight superiority of the cv. Festival, was observed, which showed that almost $80 \%$ of the responses of the panelists were in the last three categories of the scale (7-9), compared to only $67 \%$ for the cv. Oso Grande. Regarding the acceptance of appearance, the cultivars showed differences among them, with the $\mathrm{cv}$. Festival being more accepted ( 7 , liked) than the cv. Oso Grande (6, enjoyed little). However, observing Figure 1D, it can be seen that the appearance of these cultivars was accepted better than the mean indicates, the $\mathrm{cv}$. Oso Grande scored in class 7, and the cv. Festival received more than $70 \%$ of the frequency in classes of greater acceptance (7-9).

Regarding the sensory attributes of the cultivars in the hydroponic system (Table 6), according to the panelists evaluation, considerable differences were observed among cultivars for the intensity of the red color and acid taste. The cv. Festival showed the most intense red color and the Camarosa and Albion cultivars presented a higher intensity of acid taste. As for the juiciness, only the cv. Camarosa differed from the cv. Festival, presenting less juiciness. In relation to the flavor, there was no difference among cultivars. In Figure 1E, one can better visualize the sensory profile of each cultivar. The cv. Oso Grande presented a midred color, low acidity and good juiciness. The cv. Camarosa showed less intense red color, a very strong acid taste and was less juicy. The cv. Festival, in addition to its deep red color, showed mild acidic taste and good juiciness. The cv. Albion presented a sensory profile similar to the $\mathrm{cv}$. Camarosa, except for the color, which was stronger.

In Table 6 and in Figure 1F, the diagnostic attribute means of the conventional system cultivars are presented. Differences between the two cultivars were observed in regards to the red color intensity, acid taste and juiciness, however the cv. Festival had the most intense color, but it was also more acidic and less juicy than the cv. Oso Grande. Cultivars did not differ as far as the flavor.

\section{Materials and methods}

\section{Experimental conditions}

The strawberries were produced on a farm located in the municipality of Ibiapina, Ceará, Brazil, in the Ibiapaba mountainous region (latitude $3^{\circ} 58^{\prime} 21^{\prime \prime} \mathrm{S}$, longitude $40^{\circ} 52^{\prime} 2 " \mathrm{~W}$ and altitude $920 \mathrm{~m}$ ). The mean temperature and relative humidity during the production period were $21.6^{\circ} \mathrm{C}$ and $61.8 \%$, respectively, in the conventional system and $23.4^{\circ} \mathrm{C}$ and $71.2 \%$, respectively, under the plastic tunnel in the hydroponic systems.

\section{Conduction of study and experimental design}

The experiment was carried out using a completely randomized design in a factorial $4 \times 3$ scheme with four replications, represented by trays of approximately $200 \mathrm{~g}$ of fruit. The treatments consisted of four strawberry cultivars (Oso Grande, Festival, Camarosa and Albion), produced in three production systems (hydroponic in slabs and in gutters, and conventional).

The hydroponic systems were set on two wooden benches (0.8 $\mathrm{m}$ high, $1.0 \mathrm{~m}$ wide and $24.0 \mathrm{~m}$ long), spaced $0.8 \mathrm{~m}$ apart. The benches were installed under a high tunnel 
structure with tubular galvanized steel, covered with white polyethylene film of 150 microns, $3 \mathrm{~m}$ wide and $2 \mathrm{~m}$ high. Coconut fiber (Golden Mix Type 80) was used as a substrate. The nutrient solution used with electrical conductivity ranging from 1.3 to $1.5 \mathrm{dS} \mathrm{m}^{-1}$ and the $\mathrm{pH}$ ranging from 5.4 to 6.5 (Furlani and Fernandes, 2004).

The plots of the conventional system were installed outside the tunnel, next to the benches in a bed $0.2 \mathrm{~m}$ high and $1 \mathrm{~m}$ wide, covered with plastic black-white mulch, using the same technology as the grower. Before planting, the bed was fertilized with $180 \mathrm{~g} \mathrm{~m}^{-2}$ of single super phosphate.

\section{Variables measured}

The fruits were harvested 71 days after planting; ripen with a fully red skin. The strawberries were analyzed for their physicochemical properties and sensory variables. Titratable acidity (TA, \% citric acid) obtained by titration of the pulp with $\mathrm{NaOH} 0.1 \mathrm{M}$, according to the methodology of the AOAC (2005). Soluble solids (SS, ${ }^{\circ}$ Brix) the pulp was filtered on a filter paper and was measured on a digital refractometer, using the AOAC (2005) method. The SS/TA ratio was determined by dividing the values of soluble solids and titratable acidity. Soluble sugars (AS, \%) were analyzed according to Yemn and Willis (1954), in a spectrophotometer at $620 \mathrm{~nm}$. Vitamin C (mg ascorbic acid $100 \mathrm{~g}^{-1}$ pulp) was quantified by titration with DFI (2.6-dichloro-phenolindophenol) $0.02 \%$ according to Strohecker and Henning (1967). The extract for obtaining content of total extractable polyphenols (TEP, mg EGA $100 \mathrm{~g}^{-1}$ pulp) was obtained according to the Larrauri et al. (1997) methodology adapted and its determination by the Folin-Ciocalteau method (Obanda et al., 1997). For total antioxidant activity (TAA, $\mu M$ Trolox $\mathrm{g}^{-1}$ pulp), the extract used was the same as the TEP, being determined by the ABTS method used by Re et al. (1999) adapted.

In sensory analysis, strawberry samples of each system were analyzed separately. For the hydroponic system, fruit from four strawberry cultivars were analyzed. For the conventional system, due to the insufficient number of strawberries from the Albion and Camarosa cultivars only samples of the Oso Grande and Festival cultivars were analyzed. The sources of variation were the cultivars and the testers (48 individuals in each experiment). The sensory testing protocols were previously approved by the Ceará State University's Ethics in Research Committee, protocol 11044529-5.

Two acceptance tests were performed simultaneously: one on fruit appearance, and the other on its palatability (global acceptance and diagnostic attributes). Acceptance of appearance was assessed using a mixed hedonic nine-point scale, ranging from $9=$ extreme like to $1=$ extreme dislike. In the evaluation form, an assessment of the color attribute (Meilgaard et al., 1999) was also included, using an unstructured scale of $9 \mathrm{~cm}$ for the evaluation of the intensity of red, ranging from $0=$ poor to $9=$ strong.

At the taste testing, two strawberries of each cultivar, cut into halves. Samples were presented in a monadic and balanced way (Macfie et al., 1989) to minimize position effects. A test of overall acceptability using a structured hedonic scale of nine categories, ranging from "like extremely" to "dislike extremely" was applied, and a diagnosis of attributes to evaluate the intensity of the strawberry's flavor, acid taste and juiciness, through an unstructured scale of $9 \mathrm{~cm}$, similar to that used for the red coloring was used.

\section{Statistical analysis}

Data was submitted to variance analysis (ANOVA) and, for the comparison of the means, we used the Tukey test at 0.05 significance level. The Pearson's correlation analysis, at the 0.05 level of significance was also performed among the bioactive compounds and the total antioxidant activity.

\section{Conclusion}

The cultivation systems and cultivars studied influence the antioxidant activity, physicochemical and sensory properties of strawberries. The conventional system shows higher values for physicochemical variables and antioxidant activity, with cultivar variation within each system. The antioxidant activity attributed to strawberry is strongly related to the content of extractable polyphenols and vitamin C. Regarding the sensory properties, cultivars show good overall acceptability in all production systems, no presenting difference among systems.

\section{Acknowledgements}

The authors would like to acknowledge CAPES, Embrapa Tropical Agroindustry and Federal University of Ceará for supporting this study. We would like to express our appreciation also to reviewers for their suggestions for improving quality of article.

\section{References}

AOAC - Association of Official Analytical Chemists (2005) Official methods of analysis of the association of official analytical chemists. $18^{\text {th }}$. ed. Maryland. 1094p.

Atress SH, El-Mogy MM, Aboul-Anean HE, Alsanius BW (2010) Improving strawberry fruit storability by edible coating as a carrier of thymol or calcium chloride. J Hort Sci \& Ornamen Plants. 2:88-97.

Aular J, Natale W (2013) Nutrição mineral e qualidade do fruto de algumas frutíferas tropicais: goiabeira, mangueira, bananeira e mamoeiro. Rev Bras Frutic. 35:1214-1231.

Beltrán-Orozco MC, Oliva-Coba TG, Gallardo-Velázquez T, Osorio-Revilla T (2009) Ascorbic acid, phenolic content, and antioxidant capacity of red, cherry, yellow and white types of pitaya cactus fruit (Stenocereus stellatus Riccobono). Rev Agrociencia. 43:153-162.

Borsatti FC, Godoy WI, Farinácio D, Funguetto RF, Simonetti D (2009) Avaliações químicas de dez cultivares de morangueiro produzido em sistema orgânico na região sudoeste do Paraná. Rev Bras Agroecologia. 4:31-34.

Camargo LKP, Resende JTV, Tominaga TT, Kurchaidt SM, Camargo CK, Figueiredo AST (2011) Postharvest quality of strawberry fruits produced in organic and conventional systems. Hortic Bras. 29:577-583.

Chitarra MIF, Chitarra AB (2005) Pós-colheita de frutas e hortaliças: fisiologia e manuseio. $2^{\text {a }}$ ed. Lavras: UFLA. 785p. 
Costa FB, Duarte PS, Puschmann R, Finger FL (2011) Quality of fresh-cut strawberry. Hortic Bras. 29:477-484.

Figueiredo FC, Botrel PP, Teixeira CP, Petrazzini LL, Locarno M, Carvalho JG (2010) Pulverização foliar e fertirrigação com silício nos atributos físico-químicos de qualidade e índices de coloração do morango. Cienc Agrotec. 34:13061311.

Furlani PR, Fernandez Júnior F (2004) Cultivo hidropônico de morango em ambiente protegido. In: Simpósio nacional do morango \& encontro de pequenas frutas e frutas nativas do MERCOSUL, 2., Pelotas. Anais. Pelotas: Corrêa Antunez, L.E. et al. (Ed.). EMBRAPA, p.102-115. (Documentos 124).

Giménez G, Andriolo J, Godoi R (2008) Cultivo sem solo do morangueiro. Cienc Rural. 38:273-279.

Heldwein AB, Streck NA, Sturza VS, Loose LH, Zanon AJ, Toebe M, Souza AT, Peters MB, Karlec F (2010) Plastocrono e rendimento de feijão-de-vagem cultivado sob ambiente protegido e no ambiente externo em semeadura tardia no outono. Cienc Rural. 40:68-773.

Kuskoski EM, Asuero AG, Morales MT, Fett R (2006) Frutos tropicais silvestres e polpas de frutas congeladas: atividade antioxidante, polifenóis e antocianinas. Cienc Rural. 36:1283-1287.

Lado J, Rodrigo MJ, Zacarías L (2014) Maturity indicators and citrus fruit quality. Stewart Postharvest Review. 2:1-6.

Larrauri JA, Rupérez P, Saura-Calixo F (1997) Effect of drying temperature on the stabilitity of polyphenols and antioxidant activity of red grape pomace peels. J Agric Food Chem. 45:1390-1393.

Macfie HJ, Bratchell N, Greenhoff K, Vallis LV (1989) Designs to balance the effect of order of presentation and firstorder carry-over effects in hall tests. J Sens Stud. 4:129148.
Meilgaard M, Civille GV, Carr BT (1999) Sensory evaluation techniques. $3^{\text {a }}$ ed. Boca Raton: CRC, New York, 390p.

Melo EA, Maciel MIS, Lima VLAG, Nascimento RJ (2008) Capacidade antioxidante de frutas. Rev Bras Cienc Farm. 44:193-201.

Obanda M, Owuor PO, Taylor SJ (1997) Flavonol composition and caffeine content of green leaf as quality potential indicators of Kenyan black teas. J Sci Food Agric. 74:209215.

Pineli LLO, Moretti CL, Santos MS, Campos AB, Brasileiro AV, Cordova AC, Chiarello MD (2011) Antioxidants and other chemical and physical characteristics of two strawberry cultivars at different ripeness stages. J Food Compost Anal. 24:11-16.

Re R, Pellegrini N, Proteggente A, Pannala A, Yang M, RiceEvans C (1999) Antioxidant activity applying an improved ABTS radical cation decolorization assay. Free Radic Biol Med. 26:1231-1237.

Resende JTV, Morales RGF, Faria MV, Rissini ALL, Camargo LKP, Camargo CK (2010) Produtividade e teor de sólidos solúveis de frutos de cultivares de morangueiro em ambiente protegido. Hortic Bras. 28:185-189.

Siqueira HH, Vilas Boas BM, Silva JD, Nunes EE, Lima LCO, Santana MTA (2009) Armazenamento de morango sob atmosfera modificada e refrigeração. Cienc Agrotec. 33:1712-1715.

Strohecker R, Henning HM (1967) Análisis de vitaminas: métodos comprobados. Madrid, Paz Montalvo, 428p.

Taiz L, Zeiger E, Moller IM, Murphy A (2017) Fisiologia e Desenvolvimento Vegetal. $6^{\text {a }}$ ed. Porto Alegre, Artmed, 858p.

Yemn EW, Willis AJ (1954) The estimation of carbohydrate in plant extracts by anthrone. Biochem J. 57:508-514. 